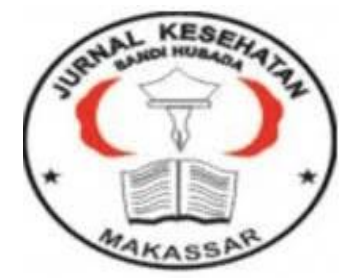

Jurnal Ilmiah Kesehatan Sandi Husada

hhttps://akper-sandikarsa.e-journal.id/JIKSH

Volume 9, Nomor 2, Desember 2020, pp 719-725

p-ISSN: 2354-6093 dan e-ISSN: 2654-4563

DOI: $10.35816 /$ jiskh.v10i2.394

\title{
Pengaruh Pemberian Monosodium Glutamat Terhadap Jumlah Sel Purkinje Cerebellum Pada Tikus
}

The Effect of Monosodium Glutamate Againsts to the Number of Cerebellar

Purkinje Cells of Rats

\author{
Ilham Nugroho \\ Pendidikan Dokter, Fakultas Kedokteran, Universitas Lampung
}

\section{Artikel info}

Artikel history:

Received; Juli 2020

Revised: Agustus 2020

Accepted; Agustus 2020

\begin{abstract}
Abstrak
Monosodium glutamat merupakan suatu garam natrium dari asam glutamat yang merupakan salah satu asam amino paling banyak ditemukan di alam. Meskipun monosodium glutamat mempunyai kemampuan untuk meningkatkan nafsu makan, sebuah kasus melaporkan bahwa monosodium glutamat dapat bersifat racun terhadap manusia dan hewan percobaan. Korteks cerebellum mengandung sel purkinje dan lapisan sel granular. Akumulasi glutamat yang berlebihan di sinapsis sel purkinje pada korteks cerebellum dapat menyebabkan penurunan kemampuan neuronal untuk mempertahankan kadar normal dari glutamat sehingga terjadi kematian sel purkinje dan gangguan fungsi sinapsis. Tujuan: Mengetahui pengaruh pemberian monosodium glutamat terhadap jumlah sel purkinje cerebellum pada tikus. Metode: Menggunakan studi literatur dari jurnal baik nasional maupun internasional dengan cara meringkas topik pembahasan dan membandingkan hasil yang disajikan dalam artikel. Hasil: Pemberian monosodium glutamat pada tikus dengan dosis 3,5 mg/gBB per hari selama 10 hari dengan administrasi parenteral mengakibatkan penurunan jumlah sel purkinje pada cerebellum tikus. Kesimpulan: Akumulasi monosodium glutamat yang berlebihan dengan glutamat sebagai komponen utama menjadi penyebab penurunan jumlah sel purkinje cerebellum pada tikus.
\end{abstract}

\section{Abstract.}

Background: Monosodium glutamate is asodium salt of glutamic acid which is one of the most common amino acids found in nature. Although monosodium glutamate has the ability to increase appetite, a case has been reported that monosodium glutamate can be toxic to humans and experimental animals. The cerebellum cortex contains purkinje cells and a layer of granular cells. Excessive accumulation of glutamate in purkinje cell synapses in the 
cerebellum cortex can cause a decrease in the neuronal ability to maintain normal levels of glutamate resulting in death of purkinje cells and impaired synaptic function. Objective: To determine the effect of monosodium glutamate administration on the number of cerebellar purkinje cells of rats. Methods: Using literature studies from both national and international journals by summarizing the topic of discussion and comparing the results presented in the article. Results: Administration of monosodium glutamate to rats at a dose of $3.5 \mathrm{mg} / \mathrm{g}$ bw per day for 10 days with parenteral administration resulted in a decrease in the number of purkinje cells in the rat's cerebellum. Conclusion: Excessive accumulation of monosodium glutamate with glutamate as the main component causes a decrease in the number of of cerebellar purkinje cells of rats.

Keywords:

Kopi Robusta;

Monosodium Glutamat;

Sel Purkinje Cerebellum;
Coresponden author:

Email: ilhamnpriyadi@gmail.com

artikel dengan akses terbuka dibawah lisensi CC BY 4.0

\section{Pendahuluan}

Monosodium glutamat (MSG) merupakan suatu garam natrium dari asam glutamat yang merupakan asam amino non-esensial dan paling banyak ditemukan di alam (Kazmi et al., 2017). Identifikasi rumus molekul asam glutamat yaitu C5H9NO4 dilakukan pertama kali oleh Ritthausen (Stańska \& Krzeski, 2016). Di dalam tubuh manusia terdapat tiga reseptor glutamat yaitu mGluR1, mGluR4, dan T1R1 + T1R3 (Kurihara, 2015). Hal tersebut mendasari pengakuan umami atau cita rasa dari glutamat secara internasional sebagai rasa dasar kelima yang diketahui berbeda dari asam, asin, manis, dan pahit (Roper, 2017). Salah satu contoh dari zat aditif pada makanan adalah monosodium glutamat yang berperan sebagai pengawet dan penambah cita rasa. Secara global, konsumsi MSG mengalami peningkatan dengan perkiraan konsumsi 3-4 g/hari sebagai bahan penyedap di berbagai macam makanan (Sharma et al., 2013). Keamanan dalam penggunaan monosodium glutamat menimbulkan berbagai kontroversi baik dalam pengamatan skala lokal maupun global. MSG mempunyai efek positif pada tubuh yaitu meningkatkan berat badan dengan cara memperbaiki kemampuan palatabilitas terhadap makanan dan meningkatkan pusat nafsu makan (Sayed et al., 2016). Selain itu, glutamat mempunyai peran dalam pembentukan ingatan dan menunjang dalam proses belajar (Hawkins \& Viña, 2016).

Meskipun MSG mempunyai kemampuan untuk meningkatkan kepekaan terhadap rasa dan memperbaiki nafsu makan, sebuah kasus melaporkan bahwa MSG dapat bersifat racun terhadap manusia dan hewan percobaan. Sebuah penelitian menunjukkan adanya kerusakan otak dengan paparan dosis MSG 3 g dan 6 g per oral selama 14 hari pada tikus Wistar dewasa. Hal tersebut membuktikan bahwa MSG bersifat toksik dan dapat mempengaruhi berbagai kondisi fisiologis dan patologis pada sistem saraf pusat mamalia (Owoeye \& Salami, 2017). Hasil observasi pada manusia menunjukkan bahwa konsumsi MSG yang berlebihan dapat menimbulkan efek samping berupa takikardia, depresi, kejang, migrain, dan timbulnya ruam pada kulit (Ashraf et al., 2017). Kekhawatiran telah meningkat mengenai konsumsi MSG yang berlebihan sebagai faktor risiko terjadinya 
obesitas berkaitan dengan kemampuan MSG untuk meningkatkan palatabilitas (He et al., 2011).

Glutamat merupakan neurotransmitter utama di cerebellum yang terutama pada bagian korteks mengandung sel purkinje dan lapisan sel granular yang tediri dari beberapa jenis tipe sel (Ashraf et al., 2017). Cerebellum merupakan suatu regio di otak yang memiliki peran penting dalam koordinasi dan kontrol pergerakan yang disadari serta proses integrasi antara persepsi sensoris dan motorik (Hashem et al., 2012). Akumulasi glutamat yang berlebihan di sinapsis sel purkinje pada korteks cerebellum dapat menyebabkan penurunan kemampuan neuronal untuk mempertahankan kadar normal dari glutamat. Hal ini memicu stimulasi yang berlebihan dari metabotropic glutamate receptors (mGluRs) dan AMPAR sehingga terjadi kaskade molekuler. Hal ini menyebabkan terjadinya peningkatan kadar kalsium intraseluler yang selanjutnya mengaktifkan enzim degradatif tergantung kalsium dan jalur apoptosis sehingga terjadi kematian sel purkinje dan gangguan fungsi sinapsis (Abass \& El-Haleem, 2011).

\section{Metode}

Metode yang digunakan adalah berupa studi literatur dari berbagai jurnal nasional maupun internasional. Metode ini digunakan dengan tujuan untuk meringkas suatu topik terkini agar meningkatkan suatu pemahaman. Studi literatur menyajikan ulang materi yang telah diterbitkan sebelumnya serta melaporkan fakta atau analisis baru dari studi literatur yang relevan kemudian membandingkan hasil tersebut dalam artikel.

\section{Hasil Dan Pembahasan}

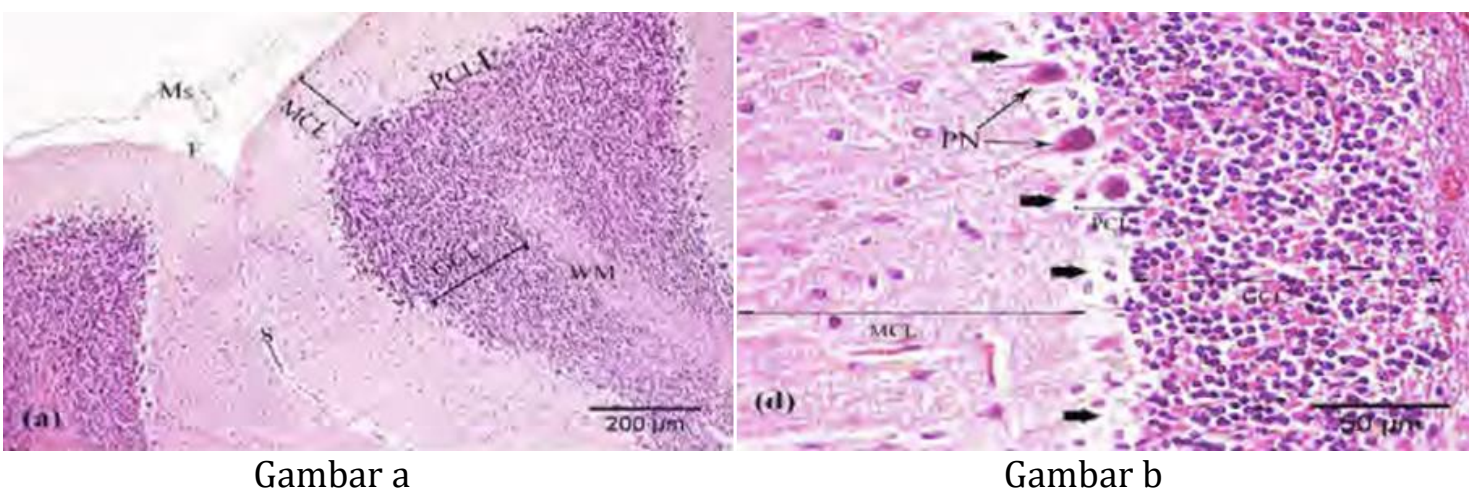

Tabel 1. Perbandingan Jumlah Sel Purkinje Cerebellum Antara Kelompok Perlakuan MSG dan Kelompok Kont

\begin{tabular}{llll}
\hline \multicolumn{1}{c}{ Kelompok } & $\begin{array}{c}\text { Jumlah Sel Purkinje } \\
\text { (Mean } \pm 2 \text { SD })\end{array}$ & Kruskal-Wallis Test & P-value \\
\hline $\begin{array}{l}\text { 1.Kelompok } \\
\text { Perlakuan MSG }\end{array}$ & $2.1 \pm 1.29$ & \multirow{2}{*}{15.661} & $0.000^{*}$ \\
\cline { 1 - 2 } 2. Kelompok Kontrol & $6.1 \pm 2.33$ & &
\end{tabular}

Pada gambar a) korteks cerebellum kelompok kontrol menunjukkan lapisan sel molekuler (MCL) dan lapisan sel purkinje (PCL) tersusun pada satu garis dengan adanya lapisan sel granular (GCL) yang padat disekitarnya. Selaput meninges tersusun utuh. Terdapat substansi putih yang jelas diisi dengan sel fusiform yang kurang padat. Folia cerebellar dipisahkan oleh sulkus yang dalam dan panjang. Pada gambar b) korteks cerebellum kelompok perlakuan MSG menunjukkan lapisan sel purkinje (PCL) dengan sel-sel nekrotik 
yang berjarak lebar. Dengan adanya pemberian MSG, efek degeneratif ditunjukkan dengan terjadinya nekrosis sel purkinje dan dibuktikan secara statistik adanya penurunan jumlah sel purkinje serta berjarak lebar karena edema (Aidaros et al., 2019).

\section{Hasil Morfometrik}

Penelitian yang dilakukan oleh Aidaros et al menunjukkan adanya perbedaan yang signifikan secara statistik antara kedua kelompok dalam hal jumlah sel purkinje ( $p$-value $<0,001$ ) karena tikus yang menerima MSG memiliki jumlah sel purkinje terendah (ratarata 2,1 sel), dibandingkan dengan kelompok kontrol (rata-rata 6,1 sel) (Aidaros et al., 2019). Dari sampel penelitian yang dilakukan oleh Prastiwi et al pada 4 kelompok perlakuan berjumlah masing-masing enam tikus, didapatkan hasil sebagai berikut (Prastiwi et al., 2015).

Tabel 2. Perkiraan Jumlah Sel Purkinje Cerebellum Pada 4 Kelompok Perlakuan

\begin{tabular}{cccccc}
\hline & \multicolumn{5}{c}{ Grup (n=6) } \\
\cline { 2 - 6 } & C & T 2.5 & T 3.0 & T 3.5 & $\begin{array}{c}\text { P- } \\
\text { value }\end{array}$ \\
\hline Jumlah Sel Purkinje & $275.9 \pm 6.2$ & $264.7 \pm 3.2$ & $262.3 \pm 3.0$ & $238.6 \pm 6.2$ & 0.000
\end{tabular}

$\left(10^{3}\right)$

Keterangan:

n : Jumlah Tikus;

C : Kontrol $2 \mathrm{ml} \mathrm{NaCl} 0.9 \%$ (intraperitoneal);

T $2.5: 2.5 \mathrm{mg} / \mathrm{g} \mathrm{BB} \mathrm{MSG}+2 \mathrm{ml} \mathrm{NaCl} 0.9 \%$ (intraperitoneal);

T $3.0: 3.0 \mathrm{mg} / \mathrm{g} \mathrm{BB} \mathrm{MSG}+2 \mathrm{ml} \mathrm{NaCl} 0.9 \%$ (intraperitoneal);

T $3.5: 3.5 \mathrm{mg} / \mathrm{g} \mathrm{BB} \mathrm{MSG}+2 \mathrm{ml} \mathrm{NaCl} 0.9 \%$ (intraperitoneal).

Penelitian yang dilakukan oleh Prastiwi et al menunjukkan analisis statistik ANOVA satu arah bahwa terdapat perbedaan yang signifikan dari kelompok dalam perkiraan jumlah sel purkinje. Perbedaan paling signifikan dengan uji post hoc multiple comparison mengungkapkan bahwa jumlah sel purkinje dari kelompok T3.5 secara signifikan lebih rendah daripada kelompok tikus lainnya (Prastiwi et al., 2015).

Penelitian yang dilakukan oleh Prastiwi et al menunjukkan bahwa pemberian monosodium glutamat pada tikus dengan dosis $3,5 \mathrm{mg} / \mathrm{gBB}$ per hari selama 10 hari dengan administrasi parenteral mengakibatkan penurunan jumlah sel purkinje pada cerebellum tikus. MSG dengan glutamat sebagai komponen utama dapat menyebabkan kematian sel Purkinje dengan mengaktivasi reseptor glutamat secara berlebihan. Sel purkinje di korteks cerebellum menerima salah satu input glutamatergik yaitu climbing fibers sehingga apabila terjadi pengaktifan reseptor glutamat secara berlebihan seperti $\mathrm{N}$ methyl-D-aspartate receptor (NMDAR), $\quad \alpha$-amino-3-hydroxy-5-methyl-4isoxazolepropionic acid receptor (AMPAR), dan kainate akibat adanya akumulasi glutamat maka dapat menyebabkan terjadinya eksitotoksis dan kematian pada sel purkinje (Prastiwi et al., 2015).

Proses eksitotoksis oleh glutamat diawali dengan proses peningkatan konsentrasi ion Ca2+ intraseluler selama 5-10 menit lalu diikuti dengan fase laten selama 2 jam dengan konsentrasi ion $\mathrm{Ca} 2+$ normal, dan terakhir terjadi kenaikan konsentrasi ion Ca2+ intraseluler secara bertahap yang diikuti dengan kematian sel. Akibat dari terjadinya kematian sel tersebut adalah pembentukan nitric oxide yang berinteraksi dengan radikal bebas superoksida membentuk peroksinitrit yang menyebabkan kerusakan DNA pada sel. Selanjutnya, kerusakan DNA yang terjadi menimbulkan aktivasi poly(ADP)-ribose 
polymerase 1 (PARP-1) secara berlebihan yang melepaskan polimer poly(ADP)-ribose (PAR) ke sitoplasma yang selanjutnya akan mengaktivasi calpains. Aktivasi calpains menyebabkan sintesis apoptosis-inducing factor (AIF) oleh mitokondria yang menyebabkan peristiwa fragmentasi DNA, kondensasi kromatin, dan kematian sel (Lau dan Tymianski, 2010). Kematian sel jalur apoptosis tergantung caspase merupakan kematian sel oleh glutamat yang terjadi di sel kortikal primer yang melibatkan aktivasi caspase-3 dan calpain serta produksi apoptosis-inducing factor (AIF) dari mitokondria ke sitosol dan inti sel. Proses mediasi apoptosis dipengaruhi oleh adanya Caspase yang merupakan suatu protease sistein (King et al., 2013).

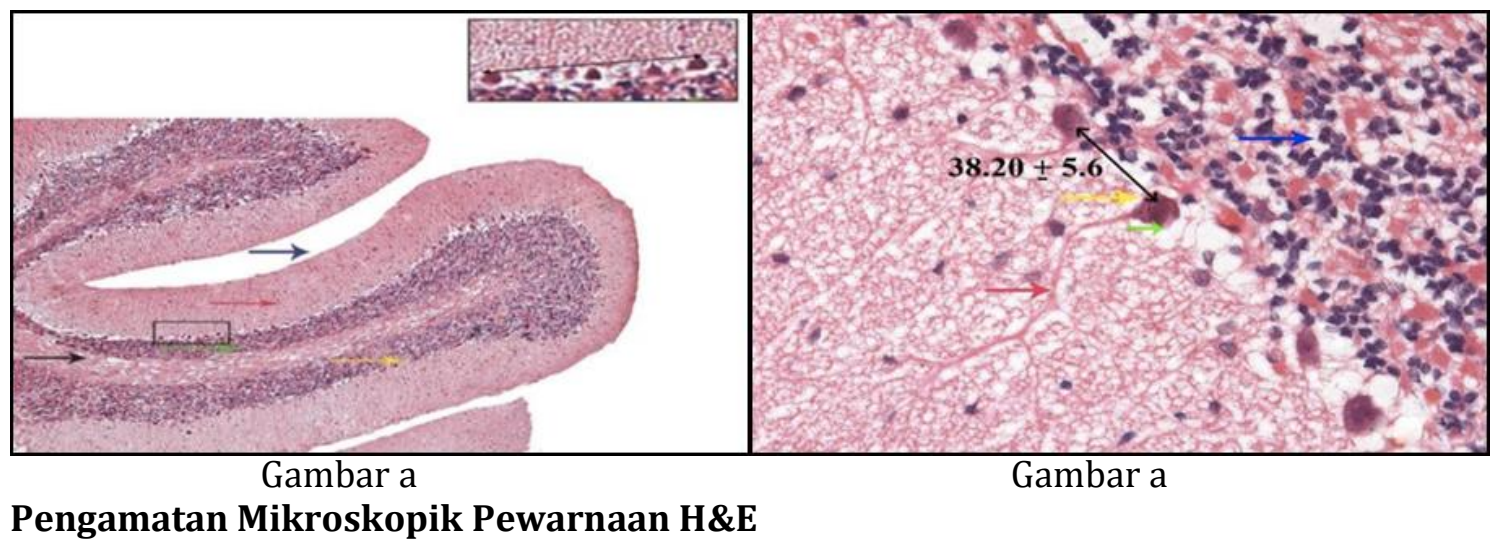

Pada gambar a) korteks cerebellum kelompok kontrol menunjukkan gambaran histologis cerebellum normal dengan tiga lapisan sel kortikal yang tersusun dengan baik. Lapisan molekuler yang hampir bebas ditempati sebagian besar oleh akson dan dendrit, lapisan tunggal sel purkinje besar, dan lapisan padat sel granular dan substansi putih di tengah setiap folium. Panah berwarna kuning menunjukkan lapisan sel purkinje. Panah berwarna merah menunjukkan lapisan molekuler. Panah berwarna hijau menunjukkan lapisan granuler. Panah berwarna hitam menunjukkan axon pada substansi putih cerebellum. Panah berwarna biru menunjukkan fissura cerebellum. Jumlah sel purkinje pada pengamatan adalah $23.00 \pm 6.43$. Pada gambar b) korteks cerebellum kelompok perlakuan dengan pemberian MSG 6 gram menunjukkan jarak antara sel purkinje yang berdekatan menjadi semakin lebar apabila dibandingkan dengan kelompok kontrol. Panah berwarna kuning menunjukkan sel purkinje. Panah berwarna hijau menunjukkan inti sel dari sel purkinje. Panah berwarna merah menunjukkan dendrit sel purkinje bergeser ke lapisan molekuler. Panah berwarna biru menunjukkan inti sel gelap pada lapisan granuler. Jumlah sel purkinje pada pengamatan adalah $25.00 \pm 6.00$. Gambaran histologis cerebellum menunjukkan adanya sedikit peningkatan jumlah sel purkinje jika dibandingkan dengan kelompok kontrol, yang secara statistik terbukti tidak signifikan. MSG dilaporkan bahwa dalam kultur sel neuron dapat menyebabkan apoptosis dan nekrosis (Ashraf et al., 2017).

Dari sampel penelitian yang dilakukan oleh Hashem et al pada 2 kelompok perlakuan berjumlah masing-masing sepuluh tikus, didapatkan hasil sebagai berikut (Hashem et al., 2012). 


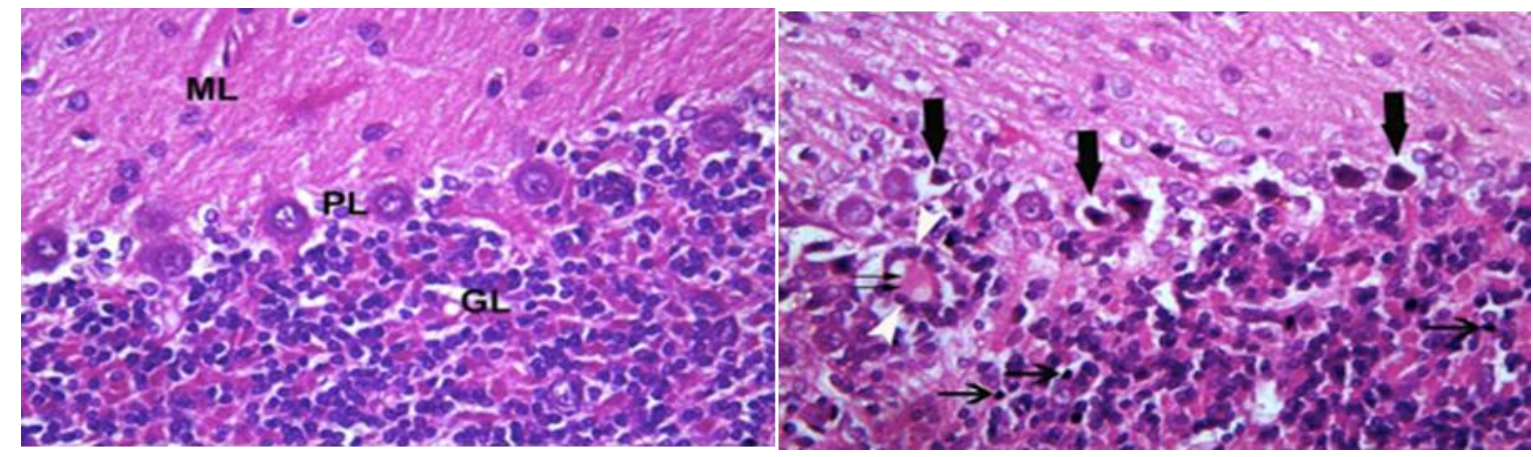

Gambar a

Gambar b

\section{Pengamatan Mikroskopik Pewarnaan H\&E}

Pada gambar a) korteks cerebellum kelompok kontrol menunjukkan bahwa korteks cerebellum terdiri dari lapisan molekuler superfisial yang terdiri dari sel dan serat yang tersebar; lapisan dalam sel granuler tersusun oleh inti padat; dan lapisan sel purkinje yang muncul sebagai satu lapisan kontinyu dari sel besar di persimpangan antara lapisan molekuler superfisial dan lapisan dalam sel granuler. Pada gambar b) korteks cerebellum kelompok perlakuan dengan pemberian MSG menunjukkan beberapa sel purkinje dengan sitoplasma berwarna gelap dan inti gelap yang menyusut. Pemeriksaan lapisan granuler menunjukkan beberapa sel dengan inti gelap. Area degenerasi yang dikelilingi oleh sel inflamasi juga terlihat. Panah tebal menunjukkan sel purkinje gelap yang menyusut. Panah tipis menunjukkan sel granuler dan panah ganda menunjukkan area degenerasi yang dikelilingi oleh sel inflamasi ditandai dengan kepala panah (Hashem et al., 2012).

Tubuh manusia menerima glutamat dari dua sumber utama yaitu baik dari makanan yang mengandung glutamat bebas (komponen alami atau ditambahkan dalam bentuk MSG) maupun dari hasil pencernaan protein (Wijayasekara \& Wansapala, 2017). Tingkat glutamat bebas yang terkandung di tubuh orang dewasa yaitu sekitar 10 gram serta memiliki konsentrasi glutamat yang tinggi pada otak yaitu 12,0 $\mu \mathrm{mol} / \mathrm{g}$ (Henry-Unaeze, 2017). Adanya karakteristik $\neg$ blood-brain barrier di otak yang bersifat impermeabel terhadap glutamat dan efektif dapat membatasi masuknya glutamat dari darah ke dalam otak sehingga tingkat konsentrasi glutamat di otak akan tetap stabil (Fernstrom, 2018).

\section{Simpulan Dan Saran}

Konsumsi monosodium glutamat yang berlebihan dapat mempengaruhi struktur histologi serta menyebabkan penurunan jumlah sel purkinje pada cerebellum. Sel purkinje dan sel granular pada kelompok yang diberikan monosodium glutamat menunjukkan beberapa gangguan seluler dan perubahan degeneratif. Dengan ditemukan hasil penelitian ini, terdapat adanya kemungkinan bahwa fungsi cerebellum sebagai organ untuk koordinasi dan kontrol gerakan sukarela dapat terpengaruh secara merugikan. Disarankan agar penelitian lebih lanjut dilakukan untuk menguatkan temuan ini.

\section{Daftar Rujukan}

Abass, M. A., \& El-Haleem, M. R. A. (2011). Evaluation of monosodium glutamate induced neurotoxicity and nephrotoxicity in adult male albino rats. J Am Sci, 7(8), 264-76.

Aidaros, A. E. E., Ibrahim, A. A., Mohammed, H. O., \& Hassan, N. H. (2019). Effect of monosodium glutamate on the cerebellar cortex of male albino rat and protective role of vitamin C. ZUMJ, 25(2), 250-60. 
Ashraf, S., Yasoob, M., Amin, M., Khan, M. A., \& Bukhari, M. H. (2017). Effects of monosodium glutamate on purkinje cells of the cerebellum of adult albino rats. APMC, 11(1), 1-5.

Fernstrom, J. D. (2018). Monosodium glutamate in the diet does not raise brain glutamate concentrations or disrupt brain functions. Ann Nutr Metab, 73(5), 43-52. https://doi.org/10.1159/000494782

Hashem, H. E., Safwat, M. D. E., \& Algaidi, S. (2012). The effect of monosodium glutamate on the cerebellar cortex of male albino rats and the protective role of vitamin $\mathrm{C}$ (histological and immunohistochemical study). J Mol Hist, 43, 179-86. https://doi.org/10.1007/s10735-011-9380-0

Hawkins, R. A., \& Viña, J. R. (2016). How glutamate is managed by the blood-brain barrier. MDPI, 5(37), 1-7. https://doi.org/10.3390/biology5040037

He, K., Du, S., Xun, P., Sharma, S., Wang, H., Zhai, F., \& Popkin, B. (2011). Consumption of monosodium glutamate in relation to incidence of overweight in Chinese adults: China Health and Nutrition Survey (CHNS). Am J Clin Nutr, 93, 1328-36. https://doi.org/10.3945/ajcn.110.008870

Henry-Unaeze, H. N. (2017). Update on food safety of monosodium L-glutamate (MSG). Pathophysiol, 24, 243-9.

Kazmi, Z., Fatima, I., Perveen, S., \& Malik, S. S. (2017). Monosodium glutamate: review on clinical reports. Int J Food Prop, 20(2), 1807-15. https://doi.org/10.1080/10942912.2017.1295260

King, A. E., Southam, K. A., Dittmann, J., \& Vickers, J. C. (2013). Excitotoxin-induced caspase3 activation and microtubule disintegration in axons is inhibited by taxol. Acta Neuropathol Commun, 1(59), 1-9. https://doi.org/10.1186/2051-5960-1-59

Kurihara, K. (2015). Umami the fifth basic taste: history of studies on receptor mechanisms and role as a food flavor. Biomed Res Int, 2015, 1-10. http://dx.doi.org/10.1155/2015/189402

Lau, A., \& Tymianski, M. (2010). Glutamate receptors, neurotoxicity and neurodegeneration

Eur J Physiol, 460, 525-42. https://doi.org/10.1007/s00424-010-0809-1

Owoeye, O., \& Salami, O. A. (2017). Monosodium glutamate toxicity : sida acuta leaf extract ameliorated brain histological alterations, biochemical and haematological changes in Wistar rats. Afr J Biomed Res, 20(2), 173-82.

Prastiwi, D., Djunaidi, A., \& Partadiredja, G. (2015). High dosage of monosodium glutamate causes deficits of the motor coordination and the number of cerebellar Purkinje cells of rats. Hum Exp Toxicol, 1-9. https://doi.org/10.1177/0960327115572706

Roper, S. D. (2017). Taste: mammalian taste bud physiology. Neurosci Biobehac Rev, 1-9. http://dx.doi.org/10.1016/B978-0-12-809324-5.02908-4

Sayed, H. Y. M., Abd-Elhalim, D. M., Hussain, M. A., \& Korayem, H. E. (2016). Monosodiumglutamate-induced cerebellar toxicity; possible role of nitric oxide in adult albino rats. Am J Sci, 12(1), 123-31.

Sharma, A., Prasongwattana, V., Cha'on, U., Selmi, C., Hipkaeo, W., \& Boonnate, P., et al. (2013). Monosodium glutamate (MSG) consumption is associated with urolithiasis and urinary tract obstruction in rats. PLoS ONE, 8(9), 1-9. https://doi.org/10.1371/journal.pone.0075546

Stańska, K., \& Krzeski, A. (2016). The umami test: from discovery to clinical use. Otolaryngol Pol, 70(4), 10-15. https://doi.org/10.5604/00306657.1199991

Wijayasekara, K., \& Wansapala, J. (2017). Uses, effects and properties of monosodium glutamate (MSG) on food \& nutrition. Int J Food Sci Nutr, 2(3), 132-43.. 